\author{
Marquette University \\ e-Publications@Marquette
}

Biological Sciences Faculty Research and

Publications

Biological Sciences, Department of

8-2013

\title{
Are lianas more drought-tolerant than trees? A test for the role of hydraulic architecture and other stem and leaf traits
}

\author{
Masha T. van der Sande \\ Wageningen University and Research Centre \\ Lourens Poorter \\ Wageningen University and Research Centre \\ Stefan A. Schnitzer \\ Marquette University, stefan.schnitzer@marquette.edu \\ Lars Markesteijn \\ University of Wisconsin- Milwaukee
}

Follow this and additional works at: https://epublications.marquette.edu/bio_fac

Part of the Biology Commons

\section{Recommended Citation}

van der Sande, Masha T.; Poorter, Lourens; Schnitzer, Stefan A.; and Markesteijn, Lars, "Are lianas more drought-tolerant than trees? A test for the role of hydraulic architecture and other stem and leaf traits" (2013). Biological Sciences Faculty Research and Publications. 697.

https://epublications.marquette.edu/bio_fac/697 
Marquette University

e-Publications@Marquette

\section{Biology Faculty Research and Publications/College of Arts and Sciences}

This paper is NOT THE PUBLISHED VERSION; but the author's final, peer-reviewed manuscript. The published version may be accessed by following the link in the citation below.

Oecologia, Vol. 172, No. 4 (August, 2013): 961-972. DOI. This article is (C) Springer and permission has been granted for this version to appear in e-Publications@Marquette. Springer does not grant permission for this article to be further copied/distributed or hosted elsewhere without the express permission from Springer.

\section{Are lianas more drought-tolerant than trees? A test for the role of hydraulic architecture and other stem and leaf traits}

Authors:

Masha T. van der Sande

Forest Ecology and Forest Management Group, Wageningen University and Research Centre, Wageningen, The Netherlands

Lourens Poorter

Forest Ecology and Forest Management Group, Wageningen University and Research Centre, Wageningen, The Netherlands

Stefan A. Schnitzer

Department of Biological Sciences, University of Wisconsin- Milwaukee, Milwaukee, USA

Smithsonian Tropical Research Institute, Balboa, Republic of Panama

Lars Markesteijn 
Department of Biological Sciences, University of Wisconsin- Milwaukee, Milwaukee, USA

Smithsonian Tropical Research Institute, Balboa, Republic of Panama

\section{Abstract}

Lianas are an important component of Neotropical forests, where evidence suggests that they are increasing in abundance and biomass. Lianas are especially abundant in seasonally dry tropical forests, and as such it has been hypothesized that they are better adapted to drought, or that they are at an advantage under the higher light conditions in these forests. However, the physiological and morphological characteristics that allow lianas to capitalize more on seasonal forest conditions compared to trees are poorly understood. Here, we evaluate how saplings of 21 tree and liana species from a seasonal tropical forest in Panama differ in cavitation resistance $\left(P_{50}\right)$ and maximum hydraulic conductivity $\left(K_{h}\right)$, and how saplings of 24 tree and liana species differ in four photosynthetic leaf traits (e.g., maximum assimilation and stomatal conductance) and six morphological leaf and stem traits (e.g., wood density, maximum vessel length, and specific leaf area). At the sapling stage, lianas had a lower cavitation resistance than trees, implying lower drought tolerance, and they tended to have a higher potential hydraulic conductivity. In contrast to studies focusing on adult trees and lianas, we found no clear differences in morphological and photosynthetic traits between the life forms. Possibly, lianas and trees are functionally different at later ontogenetic stages, with lianas having deeper root systems than trees, or experience their main growth advantage during wet periods, when they are less vulnerable to cavitation and can achieve high conductivity. This study shows, however, that the hydraulic characteristics and functional traits that we examined do not explain differences in liana and tree distributions in seasonal forests.

\section{Introduction}

The total amount and seasonal distribution of rainfall are important factors explaining the distribution of tropical tree species along a rainfall gradient (Engelbrecht et al. 2007; Toledo et al. 2011). With severity of seasonality expected to increase with climatic change (IPCC 2007), lianas may be particularly affected, as they have been suggested to increase in abundance relative to trees with the length and intensity of the dry season (Schnitzer 2005; DeWalt et al. 2010; but see Van der Heijden and Phillips 2008). Lianas are an important component of tropical forests, comprising up to $25 \%$ of the abundance and species diversity of woody stems (Schnitzer and Bongers 2011). With increasing drought, lianas may be expected to increase in abundance and thereby affect the overall species composition and distribution in tropical forests. However, little is known about why lianas would be more successful than trees with decreasing rainfall. Here, we evaluate how hydraulic architecture, photosynthetic leaf traits (maximum assimilation rate, stomatal conductance, and water use efficiency), and morphological leaf and stem traits (wood density, maximum vessel length, Huber value, specific leaf area, leaf dry matter content, and leaf size) differ between liana and tree saplings in a tropical seasonal moist forest in order to explain their differences in performance and distribution.

Among land plants, there are two main strategies to deal with drought. Species either avoid drought stress, for example by means of a deciduous leaf habit or a deep root system that ensures continued water uptake from deeper and wetter soil layers during the dry season (Restom and Nepstad 2004; Andrade et al. 2005; Markesteijn and Poorter 2009), or species can be drought-tolerant, showing low stomatal conductance to 
reduce water loss (Nardini and Salleo 2000) and high resistance to xylem cavitation to ensure continued hydraulic conductivity under drier conditions (Tyree and Sperry 1989; Markesteijn et al. 2011). Many adaptations that increase cavitation resistance come at the expense of reduced hydraulic conductivity (Ewers et al. 1990; Maherali et al. 2006). For example, narrow and short vessels (Ewers et al. 1990; Hacke et al. 2006) and high wood density (Hacke and Sperry 2001) increase the resistance to xylem cavitation, but simultaneously reduce stem hydraulic conductivity by increasing hydraulic resistance. Low conductivity implies less water reaching the leaves and, hence, limited maximum photosynthetic carbon gain (Santiago et al. 2004) and reduced growth rates (Poorter et al. 2010). Variation among species in hydraulic architecture is thus important to explain species performance and distribution in seasonal tropical forests (Sterck et al. 2011).

Lianas generally have wide and long vessels that would facilitate high hydraulic conductivity, high stomatal conductance, and high photosynthetic carbon gain (Ewers et al. 1990; Cai et al. 2009). Lianas should therefore achieve high growth rates during the wet season, but have a poor performance during the dry season due to an increased risk of xylem cavitation. An initial comparison between six tree and liana species indeed showed higher hydraulic conductivity and lower cavitation resistance in lianas (Zhu and Cao 2009). Therefore, their vulnerability to cavitation fails to explain why lianas grow relatively faster than trees during the dry season (Schnitzer 2005) and why liana densities are higher in seasonally dry forests (Schnitzer 2005; DeWalt et al. 2010).

Alternatively, the better drought performance of lianas compared to trees might be explained by differences in other photosynthetic and morphological traits. For example, compared to trees, lianas may have a higher photosynthetic water use efficiency, which could favor lianas in drier areas (Cai et al. 2009). Lianas are climbing plants with narrow and flexible stems that should have a higher leaf area per sapwood area (i.e. Huber value) compared to trees (Ewers and Fisher 1991). Therefore, lianas have more photosynthetic area and should have faster biomass growth rates than trees (Cai et al. 2007). Fast growth is also facilitated by cheaper wood and leaf construction costs (i.e., low wood density, low leaf dry matter content, and high specific leaf area) (Santiago and Wright 2007; Zhu and Cao 2009). Furthermore, high growth rates may be sustained by a deep root system, which facilitates water and nutrient acquisition from deeper soil layers during the dry season (Andrade et al. 2005).

Whereas many studies have examined hydraulic architecture of woody plants in general (e.g., Tyree and Ewers 1991; Maherali et al. 2004, 2006), few addressed differences in cavitation resistance between trees and lianas (but see Zhu and Cao 2009). Here, we evaluate how saplings of 21 tree and liana species differ in hydraulic architecture and how saplings of 24 tree and liana species differ in four photosynthetic leaf traits and six morphological stem and leaf traits, known to be important for a plant's heat, water, and carbon balance. We hypothesize that the wider and longer vessels of lianas will result in higher hydraulic conductivity and consequently higher photosynthetic rates, and in lower cavitation resistance than trees. Furthermore, we expect that lianas will have lower photosynthetic water use efficiency than trees, and that the morphological stem and leaf traits of lianas will be representative for species that are fast growing under favorable conditions.

\section{Materials and methods}

\section{Study area}

This study was conducted in a semi-deciduous seasonally moist forest in Parque Nacional Soberania, halfway the Isthmus of Panama $\left(9^{\circ} 10^{\prime} \mathrm{N}, 79^{\circ} 7^{\prime} \mathrm{W}\right.$ ) (Sakai and Wright 2008). The area has a mean annual precipitation of 2,400 mm, of which about $92 \%$ occurs during the 8-month wet season (mid-April-mid-December) (Sakai and 
Wright 2008). The area is covered with late secondary, semi-deciduous, seasonal tropical forest that has been relatively undisturbed since the construction of the Panama Canal at the turn of the nineteenth century (19041914). Data were collected along Pipeline Road where the forest was routinely disturbed and therefore assumed to be younger, with higher light availability and relatively more pioneer and less shade tolerant species than adjacent forest.

\section{Species collection}

In total, 11 liana and 13 tree species were collected, representing a total of 16 families (6 for lianas and 11 for trees) (Table 1). Of the liana species, 8 were used for measurements of cavitation resistance and hydraulic conductivity, while 3 others were omitted because we had not enough data to construct reliable vulnerability curves. Tree and liana species were selected based on their high abundance, as well as variation in shade tolerance (pioneer and shade tolerant) among tree species, and variation in growth form (climbing and selfsupporting in the sapling stage) among liana species (Table $\underline{1}$ ), in order to include species with a variety of shade tolerance levels. Selected individuals were all saplings between 1 and $2 \mathrm{~m}$ tall, and were collected from the beginning of February until mid-April 2011. The collected saplings were growing in similar high light environments along a forest road, soil conditions were kept as similar as possible, and all plants were collected at similar elevation, in order to minimize phenotypic trait variation caused by differences in environmental conditions.

\section{Table 1}

Species names with family and growth strategy [lianas: self-supporting (SS) or structural parasites (SP); trees: shade-tolerant (ST) or pioneer $(P I)]$, average xylem pressure at $50 \%$ loss of hydraulic conductivity $\left(P_{50} ; \mathrm{MPa}\right)$, slope at $P_{50}$ (Slope; \% $\mathrm{MPa}^{-1}$ ), sapwood-specific hydraulic conductivity $\left(\mathrm{K}_{\mathrm{s}} ; \mathrm{mol} \mathrm{m}^{-1} \mathrm{~s}^{-1} \mathrm{MPa}^{-1}\right.$ ), and leaf-specific hydraulic conductivity $\left(\mathrm{K}_{\mathrm{l}} ; \mathrm{mmol} \mathrm{m}^{-1} \mathrm{~s}^{-1} \mathrm{MPa}^{-1}\right)$ 


\begin{tabular}{|c|c|c|c|c|c|c|}
\hline Species & Family & $\begin{array}{l}\text { Growth } \\
\text { strategy }^{\mathrm{a}}\end{array}$ & $\boldsymbol{P}_{50}(\mathrm{Mpa})$ & $\begin{array}{l}\begin{array}{l}\text { Slope } \\
(\% \\
\left.\mathrm{MPa}^{-1}\right)\end{array} \\
\end{array}$ & $K_{s}\left(\mathrm{~mol} \mathrm{~m}^{-1} \mathrm{~s}^{-1} \mathrm{MPa}^{-1}\right)$ & $K_{\text {I }}\left(\mathrm{mmol} \mathrm{m}^{-1} \mathrm{~s}^{-1} \mathrm{MPa}^{-1}\right)$ \\
\hline \multicolumn{7}{|l|}{ Liana species } \\
\hline $\begin{array}{l}\text { Calliclamys } \\
\text { latifolia }\end{array}$ & Fabaceae & SS & -1.01 & 1.50 & 517.50 & 138.15 \\
\hline $\begin{array}{l}\text { Clitoria } \\
\text { javalensis }\end{array}$ & Fabaceae & SS & -1.84 & 1.07 & 758.65 & 79.44 \\
\hline $\begin{array}{l}\text { Doliocarpus } \\
\text { dentatus }\end{array}$ & Dilleniaceae & SP & - & - & - & - \\
\hline $\begin{array}{l}\text { Machaerium } \\
\text { seemannii }\end{array}$ & Fabaceae & SP & -0.91 & 1.91 & 179.16 & 61.75 \\
\hline $\begin{array}{l}\text { Maripa } \\
\text { panamensis }\end{array}$ & Convolvulaceae & SP & -0.29 & 4.91 & 3326.25 & 362.90 \\
\hline $\begin{array}{l}\text { Mikania } \\
\text { leiostachya }\end{array}$ & Asteraceae & SP & - & - & - & - \\
\hline $\begin{array}{l}\text { Paullinia } \\
\text { glomerulosa }\end{array}$ & Sapindaceae & SS & -0.76 & 1.40 & 75.86 & 21.30 \\
\hline $\begin{array}{l}\text { Paullinia } \\
\text { rugosa }\end{array}$ & Sapindaceae & SS & -0.68 & 2.85 & 105.60 & 49.62 \\
\hline $\begin{array}{l}\text { Senna } \\
\text { undulata }\end{array}$ & Fabaceae & SP & -1.09 & 2.18 & 322.16 & 62.29 \\
\hline $\begin{array}{l}\text { Tetracera } \\
\text { portobellensis }\end{array}$ & Dilleniaceae & SP & -1.35 & 2.05 & $1,469.00$ & 185.84 \\
\hline $\begin{array}{l}\text { Uncario } \\
\text { tomentosa }\end{array}$ & Rubiaceae & SP & - & - & - & - \\
\hline Liana average & & & -0.99 & 2.23 & 844.27 & 120.16 \\
\hline \multicolumn{7}{|l|}{ Tree species } \\
\hline $\begin{array}{l}\text { Croton } \\
\text { billbergianus }\end{array}$ & Euphorbiaceae & $\mathrm{PI}$ & -0.61 & 3.28 & 800.85 & 132.53 \\
\hline $\begin{array}{l}\text { Erythrina } \\
\text { costaricensis }\end{array}$ & Fabaceae & ST & -1.17 & 2.31 & 663.45 & 120.70 \\
\hline $\begin{array}{l}\text { Eugenia } \\
\text { nesiotica }\end{array}$ & Myrtaceae & ST & -1.71 & 1.12 & 588.64 & - \\
\hline $\begin{array}{l}\text { Faramea } \\
\text { occidentalis }\end{array}$ & Rubiaceae & ST & -4.29 & 0.58 & 105.97 & 19.11 \\
\hline $\begin{array}{l}\text { Gustavia } \\
\text { superba }\end{array}$ & Lecythidaceae & $\mathrm{PI}$ & -0.75 & 2.58 & 109.37 & 30.33 \\
\hline Inga vera & Fabaceae & ST & -3.90 & 0.46 & 184.98 & 28.50 \\
\hline $\begin{array}{c}\text { Miconia } \\
\text { argentea }\end{array}$ & Melastomataceae & $\mathrm{PI}$ & -0.92 & 2.43 & 218.80 & 47.19 \\
\hline $\begin{array}{l}\text { Piper } \\
\text { reticulatum }\end{array}$ & Piperaceae & $\mathrm{PI}$ & -0.91 & 2.24 & 232.66 & 40.87 \\
\hline $\begin{array}{l}\text { Senna } \\
\text { dariensis }\end{array}$ & Fabaceae & $\mathrm{PI}$ & -2.09 & 0.94 & 137.35 & 53.37 \\
\hline $\begin{array}{l}\text { Terminalia } \\
\text { amazonia }\end{array}$ & Combretaceae & ST & -2.59 & 0.82 & 66.96 & 23.36 \\
\hline $\begin{array}{l}\text { Vismia } \\
\text { billbergiana }\end{array}$ & Clusiaceae & ST & -2.18 & 1.06 & 238.15 & 109.33 \\
\hline $\begin{array}{l}\text { Xylopia } \\
\text { panamensis }\end{array}$ & Annonaceae & ST & -2.63 & 0.76 & 131.90 & 46.06 \\
\hline $\begin{array}{l}\text { Zanthoxylum } \\
\text { panamense }\end{array}$ & Rutaceae & $\mathrm{PI}$ & -2.05 & 1.19 & 686.91 & 74.15 \\
\hline Tree average & & & -1.98 & 1.52 & 320.46 & 60.46 \\
\hline
\end{tabular}


aDivision into shade-tolerant and pioneer species was based on survivorship and growth rate in low and high canopy sites, and percentage recruitment in low canopy sites as formulated by Welden et al. (1991)

\section{Cavitation resistance}

Cavitation resistance was determined as the xylem pressure at $50 \%$ loss of hydraulic conductivity $\left(P_{50}\right)$ for five individuals per species. For three liana species, not enough hydraulic data could be collected, because of fragile stems or blocking of the vessels after cutting. Saplings were harvested in the morning (08:00-10:00 h), in order to minimize cavitation, and brought to the laboratory immediately. There, both sides of the stems were re-cut under distilled water until a stem section remained that was about $10 \%$ longer than the maximum vessel length (MVL) measured priory (see "Morphological traits"). As such, we ensured that no open vessels were included when measuring conductivity. Open vessels have a reduced hydraulic resistance and including them in our measurements would have led to an overestimation of maximum conductivity (Ennajeh et al. 2011). Both ends of the stem were then shaved with a razor blade to ensure that vessel ends were not accidentally obstructed by debris. Lateral branches and leaves were cut off under distilled water and the openings were sealed with superglue so that no leakage would occur at the leaf scars. The lower end of each of the four stems was wrapped with Parafilm ${ }^{\odot}$ to make a tight fit and connected to a hydraulic flow meter consisting of a system of Polytetrafluoroethylene (PTFE) tubes. This flow meter was connected to a water basin pressurized by a Schollander pressure chamber (Model 600; PMS Instrument, Albany, NY, USA), and an elevated water reservoir with a low hydraulic head (4-5 kPa) (cf. Sperry et al. 1988). A solution of $10 \mathrm{mmol}$ potassium chloride (KCl) in distilled and filtered $(0.2 \mu \mathrm{m})$ water was used as a conduction fluid with standardized ion composition. The stems were first connected to the water reservoir pressurized by the pressure chamber and flushed for $15 \mathrm{~min}$ at 1.5 bar to remove embolisms. Afterwards, stems were connected to the water reservoir with low pressure head $(4-5 \mathrm{kPa}$ ) for $10 \mathrm{~min}$ for the water flow to equilibrate until flow rates were constant. Maximum conductance was estimated by three times measuring the time needed to fill $1 \mu \mathrm{l}$ of a fine grated serological pipette. Subsequently, stems were uncoupled from the flow system and pressurized with a pressure sleeve (PMS Instrument) for $10 \mathrm{~min}$ first at a low pressure (e.g., 0.5 bar). After resting the stems for 10 min with both ends under water, they were re-connected to the low pressure head flow-system and conductance was measured. This sequence was repeated with increasing sleeve pressures, until conductance had declined more than $90 \%$. The percentage loss of hydraulic conductance $(\mathrm{PLC})$ was calculated as:

$\mathrm{PLC}=100-\left(K_{\mathrm{x}} / K_{\max } * 100\right)(1)$

in which $K_{\mathrm{x}}$ is the conductance ( $\mathrm{mol} \mathrm{s}^{-1} \mathrm{MPa}^{-1}$ ) measured after pressurizing and $K_{\max }$ the conductance measured after flushing. Hydraulic conductivity $\left(K\right.$; in $\left.\mathrm{kg} \mathrm{m}^{-1} \mathrm{~s}^{-1} \mathrm{MPa}^{-1}\right)$ was calculated as:

$K=\Delta V /(\Delta P / \Delta X)(2)$

where $\Delta V$ is the mass flow rate $\left(\mathrm{kg} \mathrm{s}^{-1}\right)$ and $(\Delta P / \Delta X)$ is the pressure drop (MPa) across a stem segment of length $X(\mathrm{~m})$. Vulnerability curves were made by fitting an exponential sigmoid function through all measurements of a species, using the following equation:

$\operatorname{PLC}=100 /(1+\operatorname{EXP}(a(\Psi-b)))(3)$

in which $\Psi$ is the xylem pressure corresponding to the holding pressure of the pressure sleeve, $b$ is the xylem pressure at $50 \%$ loss of hydraulic conductivity $\left(P_{50}\right)$, and $a$ is the slope at $P_{50}$ (Pammenter and Willigen $\underline{1998}$; Markesteijn et al. 2011a). A nonlinear regression analysis was used to estimate $a$ and $b$ (SPSS 18.0; SPSS, 
Chicago). Curve-fitting and estimations for $a$ and $b$ were done for a minimum of 15 measurements per species, with the exception of Paullinia glomerulosa and Eugenia nesiotica, for which respectively only 8 and 6 measurements were made. Analyses of $a$ and $b$ were not quantitatively affected by the inclusion of these two species.

\section{Maximum hydraulic conductivity}

Maximum hydraulic conductivity $\left(K_{h}\right)$ was measured using the same procedure as described above. For each species, 5 individuals were measured, with the exception of $P$. glumerulosa, E. nesiotica, and M. panamensis for which respectively 4,4 , and 3 individuals were measured. For each individual, stem diameter (excluding bark) and pith diameter were measured, and the sapwood area was calculated by subtracting the pith area from the stem area. As saplings have relatively little nonconductive xylem, all sapwood was assumed to be conductive. For each individual, total leaf dry mass, and the leaf area and leaf dry mass of a subsample, were measured. Total leaf area was then calculated by multiplying total leaf dry mass with the ratio of leaf area to leaf mass of the subsample (see also "Morphological traits"). Leaf-specific hydraulic conductivity $\left(K_{\mathrm{I}}\right)$ and sapwood-specific hydraulic conductivity $\left(K_{s}\right)$ were calculated by dividing $K_{\mathrm{h}}$ by the total leaf area above the measured stem section and sapwood area of the upper distal cut, respectively. Finally, $K_{\mathrm{s}}\left(\mathrm{mol} \mathrm{m}^{-1} \mathrm{~s}^{-1} \mathrm{MPa}^{-1}\right)$ and $K_{1}\left(\mathrm{mmol} \mathrm{m}^{-1} \mathrm{~s}^{-1} \mathrm{MPa}^{-1}\right)$ were expressed in molar mass by multiplication with the molar mass of water $\left(18.02 \mathrm{~g} \mathrm{~mol}^{-1}\right)$. It should be noted that $K_{\mathrm{s}}$ and $K_{\text {। }}$ express the maximum hydraulic capacity without any stress of atmospheric and edaphic drought, but that the actual in situ hydraulic conductivity will be lower.

\section{Morphological traits}

For every individual, we took a sample of the main stem, excluding the bark, and determined its fresh volume with the water displacement method. Five selected leaves per individual sapling were pooled and rehydrated overnight, after which fresh mass and leaf area were measured. Leaf and stem samples were then oven-dried for $48 \mathrm{~h}$ at $75^{\circ} \mathrm{C}$, and their dry mass was measured with a microbalance. Total leaf area was estimated using the ratio of leaf area to dry mass calculated per subsample, and multiplying this with total dry mass.

Average leaf size $\left(\mathrm{LS} ; \mathrm{Cm}^{2}\right)$ was calculated by dividing leaf area of the subsample by the number of leaves in the subsample. Specific leaf area (SLA; $\mathrm{cm}^{2} \mathrm{~g}^{-1}$ ) was calculated by dividing leaf size by leaf dry mass and leaf dry matter content (LDMC; $\mathrm{g} \mathrm{g}^{-1}$ ) was calculated by dividing leaf dry mass by leaf fresh mass. Wood density (WD; $\mathrm{g} \mathrm{cm}^{-3}$ ) was determined by dividing stem dry mass by stem fresh volume. The Huber value $\left(\mathrm{Hv} ; \mathrm{cm}^{2} \mathrm{~cm}^{-2}\right)$ was calculated as the sapwood area at the upper distal cut divided by total leaf area it supported. Finally, maximum vessel length (MVL; $\mathrm{cm}$ ) was measured for five individuals per species with the air injection method (Greenidge 1952). We used the pressure chamber to pressurize the stems at 1-1.5 bar and re-cut the stems under water, about $1 \mathrm{~cm}$ at a time, until air bubbles emerged. Escaping air indicated that the longest vessel element was opened and hence the MVL could be measured from the length of the remaining stem.

\section{Photosynthetic traits}

For each species, five individuals were marked along Pipeline road at the end of the dry season, between the end of March and the beginning of April 2011. Due to a La Niña event, the dry season was wetter than regular years, nonetheless conditions were relatively dry, with $22 \mathrm{~mm}$ precipitation in March and $77 \mathrm{~mm}$ in April 2011, compared to the monthly average of $266 \mathrm{~mm}$ for the rest of 2011 (Meteorology and Hydrology Department, Panama Canal Authority). Between 07:00 and 11:00 h, maximum photosynthesis per unit leaf area ( $A$ area; $\mu \mathrm{mol} \mathrm{m} \mathrm{m}^{-2} \mathrm{~s}^{-1}$ and stomatal conductance $\left(g \mathrm{~s} ; \mathrm{mol} \mathrm{m}^{-2} \mathrm{~s}^{-1}\right)$ were measured for each individual with a LI-COR $6400 x t$ (Li-Cor, Lincoln, NE, USA) at an irradiance of $1,000 \mu \mathrm{mol} \mathrm{s}^{-1} \mathrm{~m}^{-2}$. Measurements were taken after 
photosynthesis was fully induced and photosynthetic rates were stable. Photosynthetic capacity per unit biomass ( $A$ mass; $\mu \mathrm{mol} \mathrm{g}{ }^{-1} \mathrm{~s}^{-1}$ ) was calculated by dividing $A$ areaby SLA and by 10,000 (to convert from $\mathrm{cm}^{2}$ to $\mathrm{m}^{2}$ ), and water use efficiency (WUE; $\mu \mathrm{mol} \mathrm{mol}{ }^{-1}$ ) was calculated by dividing $A$ area by $g$ s.

\section{Data analysis}

All variables were averaged per species and Ln-transformed when necessary to get a normal distribution. To evaluate whether trees and lianas differed in their multivariate trait characteristics, we first did a MANOVA, using all 14 traits as dependent variables. To evaluate whether trees and lianas differed significantly in specific traits, we used an independent samples $t$ test, with individual hydraulic properties $\left(P_{50}\right.$, slope, $K_{\mathrm{s}}$ and $\left.K_{1}\right)$, photosynthetic traits ( $A_{\text {area }}, A_{\text {mass }}, g_{\mathrm{s}}$ and WUE) and morphological traits (WD, MVL, Hv, SLA, LDMC, and LS) as dependent variables. All analyses were performed with SPSS 18.0 (SPSS, Chicago). Within-group variation was evaluated for all traits by calculating the coefficient of variation.

\section{Results}

All species lost hydraulic conductivity with decreasing xylem water potential, but the vulnerability curves differed largely in shape and position, varying from strongly sigmoid (e.g., Faramea occidentalis) to sloping (e.g., Miconia argentea) (Figs. 1, 2). The curves explained 80-97\% of the relationship between percentage loss of conductivity and xylem pressure. The xylem pressure at $50 \%$ loss of hydraulic conductivity $\left(P_{50}\right.$; parameter $b$ in Eq. $\underline{3}$ ) indicates how fast cavitation occurs, and the maximum slope at $P$ 50 (parameter $a$ in Eq. $\underline{3}$ ) indicates how fast cavitation spreads to other vessels, with low $P_{50}$ and low slope representing a cavitationresistant species. $P_{50}$ varied almost 50 -fold across species, ranging from -4.29 to $-0.29 \mathrm{MPa}$ (Table $\underline{1}$ ), and lianas and trees different significantly in $P_{50}$, with a two times higher mean for lianas $(-0.99 \mathrm{MPa})$ than for trees $\left(-1.98 \mathrm{MPa}\right.$ ) (Fig. $\underline{3}$ a). Slopes at $P_{50}$ varied 10 -fold across species, from 0.46 to $4.91 \% \mathrm{MPa}^{-1}$ (Table $\underline{1}$ ), but no differences were found between lianas (mean $=2.33 \% \mathrm{MPa}^{-1}$ ) and trees (mean $=1.53 \% \mathrm{MPa}^{-1}$ ) $($ Fig. $\underline{3} \mathrm{~b})$. 


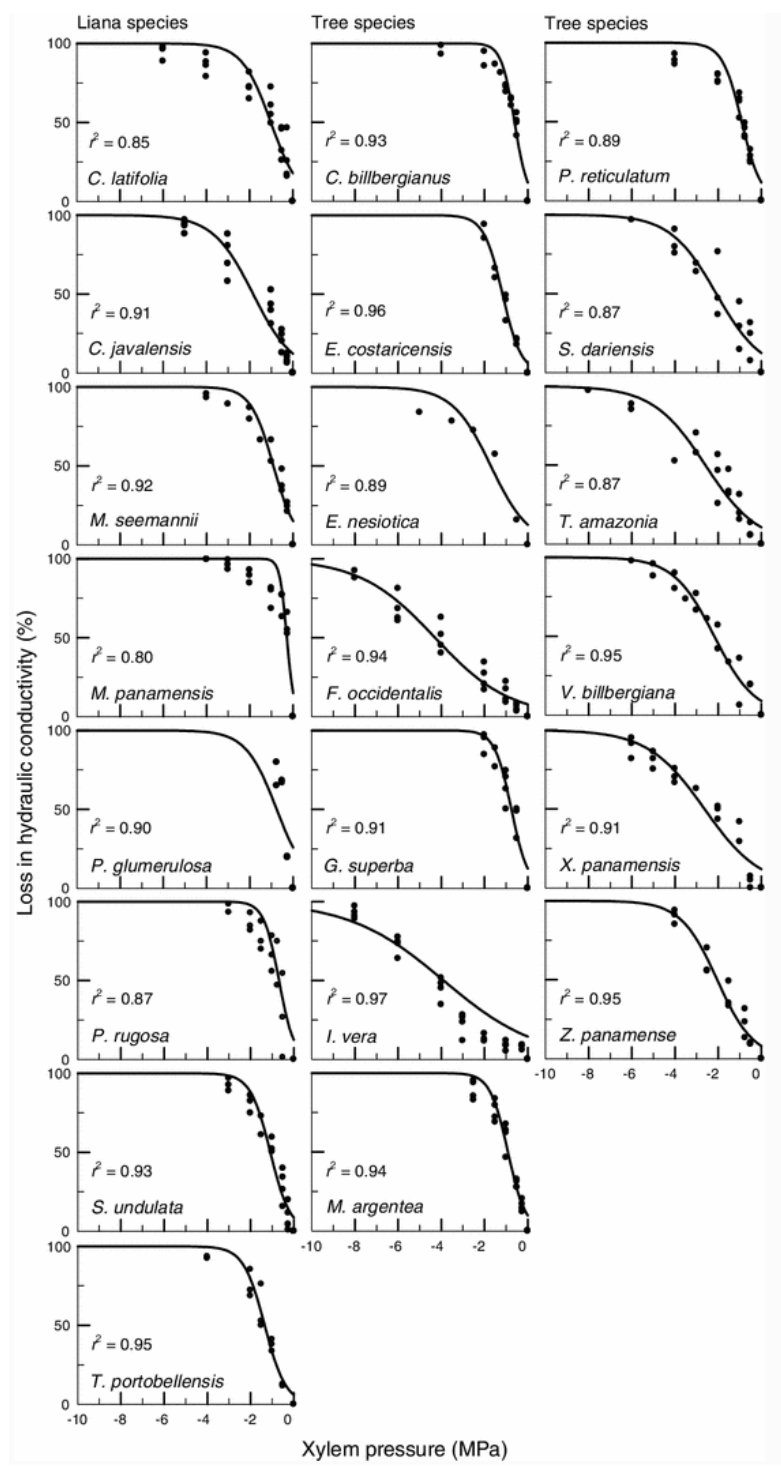

Fig. 1 Vulnerability curves for each species showing the loss in hydraulic conductivity with increasing xylem pressure. The left column presents the liana species and the middle and right columns present the tree species, all alphabetically ordered

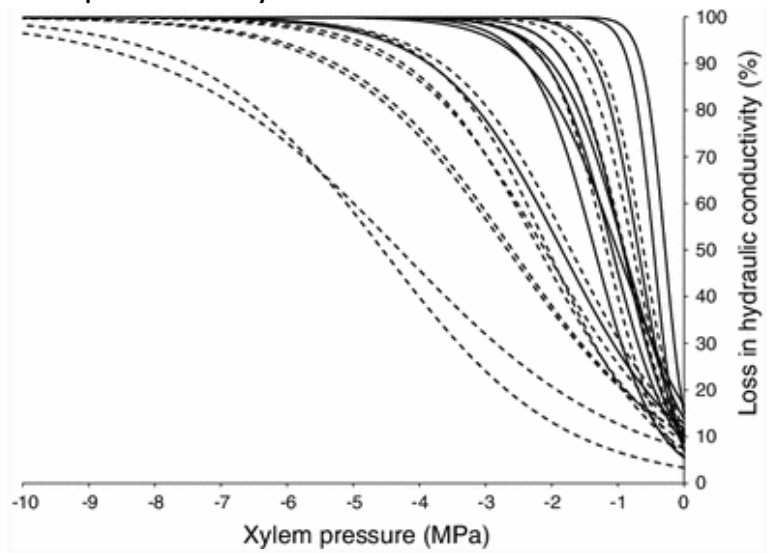

Fig. 2 Vulnerability curves showing the loss in hydraulic conductivity with increasing xylem pressure for all liana (solid lines) and tree (dashed lines) species (individually shown in Fig. 1) 

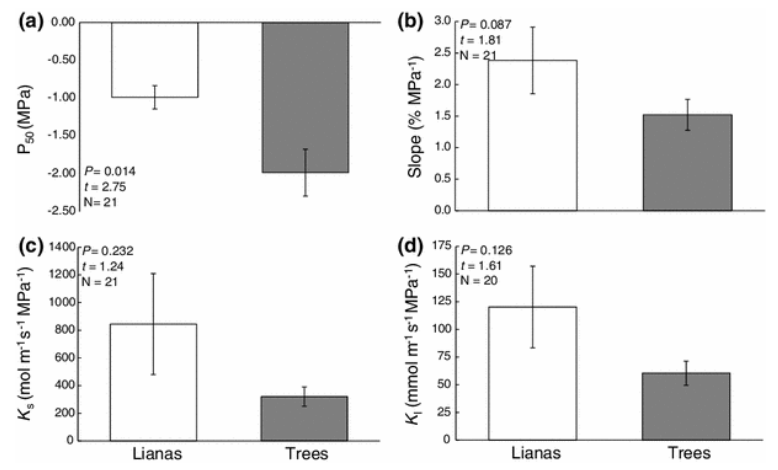

Fig. 3 Differences between lianas (white bars) and trees (gray bars) in four hydraulic traits: acavitation resistance $\left(P_{50}\right)$, b slope at $P_{50}\left(\right.$ Slope), c sapwood-specific hydraulic conductivity $\left(K_{s}\right)$, and d leaf-specific hydraulic conductivity $\left(K_{1}\right)$. Differences were compared with $t$ tests, and standard error, $P$ and $t$ values, and sample sizes $(N)$ are given

The maximum sapwood-specific hydraulic conductivity $\left(K_{s}\right)$ varied almost 50-fold among species (67$\left.3,326 \mathrm{~mol} \mathrm{~m}^{-1} \mathrm{~s}^{-1} \mathrm{MPa}^{-1}\right)$, and the leaf specific hydraulic conductivity $\left(K_{\mathrm{I}}\right)$ almost 20-fold (19$363 \mathrm{mmol} \mathrm{m}^{-1} \mathrm{~s}^{-1} \mathrm{MPa}^{-1}$ ) (Table 1), but lianas and trees did not differ significantly in $K_{\mathrm{s}}$ and $K_{\mathrm{I}}$ (Fig. $\underline{3} \mathrm{c}, \mathrm{d}$ ). However, two congeneric liana species in the Sapindaceae family (Paullinia glomerulosa and Paullinia rugosa) had extremely low conductivity. When excluding these two species, lianas had a significantly higher $K_{s}$ (liana mean $=1,095$ and tree mean $=320 \mathrm{~mol} \mathrm{~m}^{-1} \mathrm{~s}^{-1} \mathrm{MPa}^{-1} ; t=2.4, P=0.026, N=19$ ) and $K$ । (liana mean $=148$ and tree mean $=60 \mathrm{mmol} \mathrm{m}^{-1} \mathrm{~s}^{-1} \mathrm{MPa}^{-1} ; t=2.6, P=0.019, N=18$ ) than trees.

To evaluate the effect of growth form on $K_{\mathrm{s}}$ and $K_{\text {। }}$ of lianas, comparisons were made between self-supporting and climbing lianas. Self-supporting lianas did not differ from climbing lianas in $K_{s}(t$ test, $P=0.250, d f=7)$ and $K_{1}(P=0.235)$. Because $K_{s}$ and $K_{1}$ showed similar results, they will henceforward be collectively referred to as maximum hydraulic conductivity $\left(K_{h}\right)$. The hydraulic traits showed high coefficients of variation across species, both for the group of lianas and the group of trees (Table 2 ).

Table 2 Coefficients of variation (SD/mean $\times 100$ ) for all traits (for full names, see Table 1 ), calculated for lianas and trees separately

\begin{tabular}{|l|l|l|}
\hline Traits & Lianas & Trees \\
\hline$P_{50}$ & 44 & 56 \\
\hline Slope & 63 & 58 \\
\hline$K_{s}$ & 122 & 78 \\
\hline$K_{\text {। }}$ & 87 & 63 \\
\hline$A_{\text {area }}$ & 26 & 21 \\
\hline$A_{\text {mass }}$ & 20 & 53 \\
\hline$g_{s}$ & 27 & 26 \\
\hline WUE & 18 & 21 \\
\hline WD & 35 & 20 \\
\hline MVL & 59 & 39 \\
\hline$H v$ & 51 & 52 \\
\hline
\end{tabular}




\begin{tabular}{|l|l|l|}
\hline LDMC & 18 & 21 \\
\hline SLA & 14 & 33 \\
\hline LS & 85 & 84 \\
\hline
\end{tabular}

Surprisingly, trees and lianas did not differ for the multivariate analysis including all traits at once (MANOVA, $F=1.254, P=0.430, N=18$ ). Also, none of the other morphological and photosynthetic traits differed between trees and lianas when using univariate analyses ( $t$ tests) (Figs. $4, \underline{5}$ ). Coefficients of variation (CV) within each trait were relatively small (except for Huber value and leaf size). Most values were comparable for trees and lianas, but $A$ mass and SLA had higher CV for trees, and wood density and maximum vessel length had higher CV for lianas (Table $\underline{2}$ ).
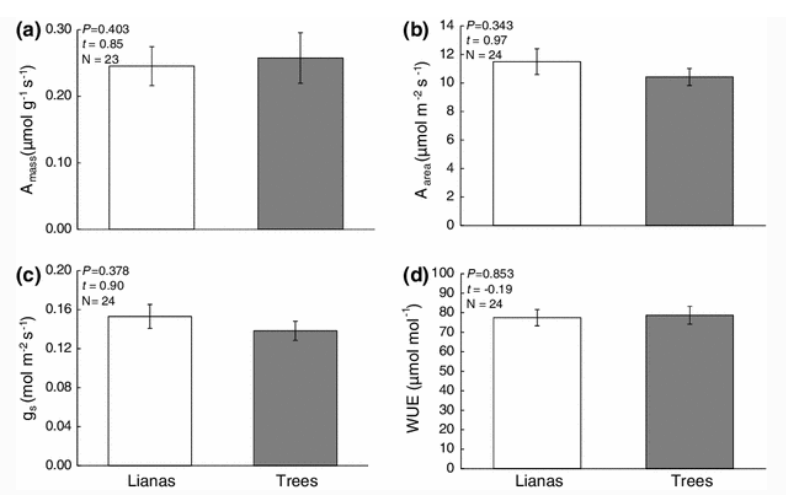

Fig. 4 Differences between lianas (white bars) and trees (gray bars) in four photosynthetic traits: a photosynthetic capacity per unit biomass ( $\left.A_{\text {mass }}\right)$ and $\mathbf{b}$ per unit leaf area $\left(A_{\text {area }}\right)$, $\mathbf{c}$ stomatal conductance $(g \mathrm{~s})$, and $\mathbf{d}$ water use efficiency (WUE). Differences were compared with $t$ tests, and standard error, $P$ and $t$ values, and sample sizes $(N)$ are given
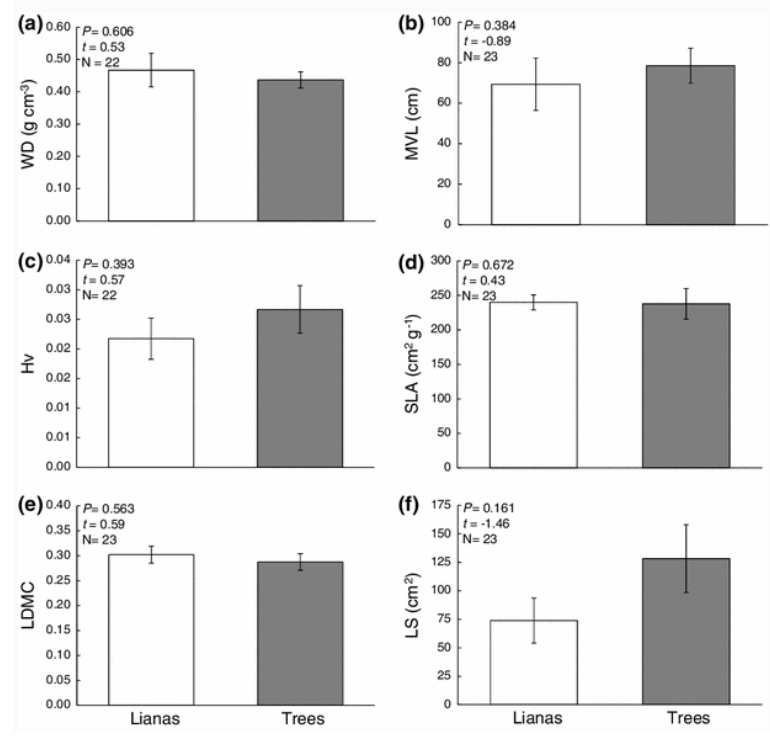

Fig. 5 Differences between lianas (white bars) and trees (gray bars) in six morphological traits: a wood density $(W D)$, b maximum vessel length (MVL), c Huber value $(H v)$, dspecific leaf area (SLA), e leaf dry matter content (LDMC), and $\mathrm{f}$ leaf size $(L S)$. Differences were compared with $t$ tests, and standard error, $P$ and $t$ values, and sample sizes $(N)$ are given 


\section{Discussion}

The aim of this study was to address how saplings of trees and lianas differ in overall hydraulic architecture and functional morphology, which we expected to be important mechanisms for explaining the relatively high liana abundances in seasonal tropical forests. At the sapling stage, lianas had lower cavitation resistance than trees, and they had higher maximum hydraulic conductivity $\left(K_{h}\right)$ only when two congeneric liana species were excluded. Furthermore, contrary to our expectations, lianas and trees did not differ in any of the other morphological and physiological traits.

\section{Lianas have a lower cavitation resistance than trees}

We hypothesized that lianas are less physiologically drought-tolerant than trees because of their wider and longer vessels that would increase their risk of cavitation (Ewers et al. 1990; Gutiérrez et al. 2009). This was confirmed by the data, as lianas had a significantly higher $P_{50}$ than trees (Fig. 3a; cf. Zhu and Cao 2009), indicating that cavitation is induced at higher xylem potentials for lianas than for trees. These differences in $P_{50}$ may be explained by the diameter of the widest vessel, as wide vessels cavitate more easily than narrow ones, and by the size of the largest pit pores in the intervascular membranes, as large pit pores are more likely to allow air-seeding to occur (Tyree and Sperry 1989; Maherali et al. 2006). Lianas and trees did not differ significantly in slope at $P_{50}$ (Fig. $\underline{3} \mathrm{~b}$ ), indicating that they have a similar rate of spread of cavitation to other vessels. The slope may both reflect the vessel diameter distribution and the distribution of the pit pore size per vessel, since a narrow distribution (i.e. with similar-sized vessel diameters or pit pores) would result in a more simultaneous cavitation of all vessels, and hence a steep slope, whereas a broad distribution results in a more gradual cavitation of vessels and a shallow slope (Ewers et al. 1990). Lianas are therefore likely to have wider vessels than trees (cf. Zhu and Cao 2009), that correlate with large pit membrane area (cf. Hacke et al. 2006), but a similar vessel size and pit pore size distribution around the mean. Maximum vessel length is the only vessel-related trait measured here, but showed no differences between tree and liana saplings. Although maximum vessel length was found to correlate with maximum vessel diameter (Ewers et al. 1990), it might not necessarily be related to mean vessel diameter and distribution. Other anatomical traits that could explain the difference in $P_{50}$ are mean rather than maximum vessel length, vessel length distribution, fiber lumen area, fiber wall thickness, and vessel elasticity (Ewers et al. 1990; Jacobsen et al. 2005; Hacke et al. 2006). Although slopes at $P_{50}$ did not differ, the higher $P_{50}$ for lianas should preclude them from dry areas, and thus physiological drought tolerance cannot explain liana occurrence in drier areas.

\section{Lianas tend to have a higher hydraulic conductivity than trees}

As lianas are geared toward fast growth rates (Cai et al. 2007; Schnitzer et al. 2004), we expected that lianas would realize higher photosynthetic rates than trees, and hence also a higher maximum hydraulic conductivity $\left(K_{h}\right)$ to support stomatal water loss (cf. Santiago et al. 2004). Lianas showed significantly higher values of sapwood-specific and leaf-specific hydraulic conductivity $\left(K_{s}\right.$ and $\left.K_{1}\right)$ than trees (Fig. $\left.\underline{3} \mathrm{c}, \mathrm{d}\right)$, but only when two liana species ( $P$. glomerulosa and $P$. rugosa), that had extremely low conductivity, were excluded (Table 1). These two Paullinia species are congeneric and self-supporting as saplings (i.e., not yet climbing), indicating that phylogenetic similarity or variation in growth form among the liana species may result in substantial variation in $K_{\mathrm{h}}$. No differences in $K_{\mathrm{s}}$ and $K_{\mathrm{l}}$ were found between self-supporting and climbing lianas, indicating that variation in self-supportiveness could not explain conductivity of lianas. However, similar comparison with a bigger sample size may result in clearer differences between different growth forms. Higher hydraulic conductivity was also found for adult lianas compared to adult trees in tropical 
rainforests in China (Zhu and Cao 2009), Mexico (Gutiérrez et al. 2009), and Panama (Santiago and Wright 2007), emphasizing the fast growth strategy of lianas.

\section{How functionally different are liana and tree saplings?}

Lianas and trees differ strikingly in their growth form, and we therefore also expected clear differences in their stem and leaf traits in the sapling stage. We hypothesized that the fast growth rates of lianas would be related to lower sapwood area per leaf area (i.e., low Huber value) and higher photosynthetic and gas exchange rates compared to trees. The acquisitive strategy of lianas would be facilitated by cheap construction costs of wood and leaves (i.e. low wood density, leaf dry matter content, and high SLA) and large leaves, but come at the expense of high water use that would increase water limitation during droughts. However, liana and tree saplings did not differ in their trait values when analyzing all traits combined, and (apart from $P_{50}$ and $K_{h}$ ) neither for the individual traits (Figs. $4, \underline{5}$ ). Other studies did find clear differences in physiological and morphological traits between adult lianas and trees (e.g., Santiago and Wright 2007; Zhu and Cao 2009, 2010; Cai et al. 2009; Asner and Martin 2010) and seedlings (Cai et al. 2007). For example, adult lianas had higher photosynthetic capacity and WUE than trees when compared during the wet (Zhu and Cao 2009) and dry season (Cai et al. 2009), and lianas had lower Huber value and higher SLA (Zhu and Cao 2009, 2010). Thus, apart from $P_{50}$ and $K_{\mathrm{h}}$, lianas and trees in our study appear to be functionally similar in the sapling stage with respect to the other traits that we measured (Table $\underline{3}$ ), which may be explained by the observation that many liana species are self-supporting (tree-like) at this life stage, although in our case saplings of only 4 out of 11 species were self-supporting and no differences in $K_{\mathrm{h}}$ were found between climbing and self-supporting lianas. More pronounced differences between lianas and trees may become apparent with ontogenetic development. For example, when lianas grow taller, they lose the capacity to support themselves, have relatively narrow stems, and as a result their Huber value decreases (Putz 1983). A reduction in the investment in stem biomass may result in an increased investment in photosynthetic leaf area and root depth in lianas relative to trees, and hence in an increased advantage of light and water acquisition for lianas relative to trees at later ontogenetic stages.

Table 3

Traits with abbreviations and units

\begin{tabular}{|c|c|c|}
\hline Abbreviation & Trait & Unit \\
\hline \multicolumn{3}{|c|}{ Hydraulic properties } \\
\hline$P_{50}$ & Xylem water potential at $50 \%$ loss of hydraulic conductivity & $\mathrm{MPa}$ \\
\hline Slope & Loss in hydraulic conductivity at $P_{50}$ & $\% \mathrm{MPa}^{-1}$ \\
\hline$K_{\mathrm{s}}$ & Sapwood-specific hydraulic conductivity & $\mathrm{mol} \mathrm{m}^{-1} \mathrm{~s}^{-1} \mathrm{MPa}^{-1}$ \\
\hline$K_{1}$ & Leaf-specific hydraulic conductivity & $\mathrm{mmol} \mathrm{m}^{-1} \mathrm{~s}^{-1} \mathrm{MPa}^{-1}$ \\
\hline \multicolumn{3}{|c|}{ Morphological traits } \\
\hline WD & Wood density & $\mathrm{g} \mathrm{cm}^{-3}$ \\
\hline MVL & Maximum vessel length & $\mathrm{cm}$ \\
\hline $\mathrm{Hv}$ & Huber value (sapwood area per leaf area) & $\mathrm{cm}^{2} \mathrm{~cm}^{-2}$ \\
\hline SLA & Specific leaf area & $\mathrm{cm}^{2} \mathrm{~g}^{-1}$ \\
\hline LDMC & Leaf dry matter content & $\mathrm{g} \mathrm{g}^{-1}$ \\
\hline LS & Average leaf size & $\mathrm{cm}^{2}$ \\
\hline \multicolumn{3}{|c|}{ Photosynthetic traits } \\
\hline$A$ area & Photosynthetic capacity per unit leaf area & $\mu \mathrm{mol} \mathrm{m} \mathrm{m}^{-2} \mathrm{~s}^{-1}$ \\
\hline$A$ mass & Photosynthetic capacity per unit leaf biomass & $\mu \mathrm{mol} \mathrm{g} \mathrm{s}^{-1}$ \\
\hline$g_{s}$ & Stomatal conductance & $\mathrm{mol} \mathrm{m} \mathrm{m}^{-2} \mathrm{~s}^{-1}$ \\
\hline
\end{tabular}


What is clear, though, is that within each life form there is a large variation in functional traits (Figs. $\underline{1}, \underline{2}, \underline{3}, \underline{4}$; Table 2). For example, our hydraulics data showed strong overlap between tree and liana species (Table $\underline{1}$ ), with on average lianas at the higher end of the conductivity spectrum and trees at the low end. The different vulnerability curves show a range of different relationships between the percentage loss of conductivity and the xylem pressure, again with overlap in cavitation resistance between trees and lianas (Figs. 1 , $\underline{2}$; Table $\underline{1}$ ). These results suggest that within the liana and tree group, species cover a range of strategies, possibly caused by differences in, for example, shade tolerance or self-supportiveness. Similarly, large across-species variation in seedling growth, survival and morphological traits was found for both lianas and trees (Gilbert et al. 2006; Cai et al. 2007; Avalos et al. 2007), which could contribute to species partitioning along resource gradients (Westoby et al. 2002; Sterck et al. 2011).

\section{What may explain liana and tree abundance in seasonal forests?}

We have tried to explain the higher relative abundance of lianas compared to trees in drier forests based on their hydraulic properties and other underlying traits. However, it should be acknowledged that many other ecological factors may explain species abundance, such as competition, predation, biogeography, and disturbance. We compared photosynthetic traits of tree and liana saplings during the dry season, but at the time of the measurements, conditions were relatively wet due to a La Niña event. It could be that differences between trees and lianas in photosynthetic traits are more pronounced during regular (i.e., shorter and more intense) dry seasons or extreme drought events (e.g., Cai et al. $\underline{2009}$ ), when competition for water and nutrients is stronger, resulting in stronger niche differentiation. For example, under more pronounced conditions, trees may shed their leaves faster than lianas (Schnitzer 2005; but see Avalos and Mulkey 1999), or may show a stronger decline in photosynthetic rates. Another explanation might be that water is not a strongly limiting factor at our seasonally moist forest site, leading to relatively small differences between lianas and trees in the suite of functional traits that we examined. Possibly, under drier conditions, larger differences can be found. This is in line with studies that show differences in traits and performance between trees and lianas in more strongly seasonal areas (e.g., Zhu and Cao 2009, 2010), but no or fewer differences in wetter forests (e.g., Santiago and Wright 2007; Sanchez-Azofeifa et al. 2009; but see Schnitzer 2005). Sanchez-Azofeifa et al. (2009) argued that lianas become functionally different from trees only with limited water (or light) availability. In our site, therefore, other factors than water availability might be more important in explaining the performance of liana species, such as light availability.

Alternatively, changes in liana and tree abundance in Neotropical forests may be explained by differences in other aspects not measured here. First, lianas may survive dry periods with the capacity to refill embolized vessels by positive root pressure (Fisher et al. 1997; but see Ewers et al. 1997). Second, lianas may have deeper roots than trees also in the sapling stage (Andrade et al. 2005). This would make them more drought-avoiding rather than physiologically drought-tolerant, in line with the dry-season growth advantage hypothesis (Schnitzer 2005). However, liana abundance increases not only with drought but also with light availability (Schnitzer et al. 2005; DeWalt et al. 2010). A third alternative is therefore that lianas may benefit more from high light than trees (Schnitzer and Bongers 2002; but see Gilbert et al. 2006), or compete better under such conditions. The relative growth advantage of adult lianas over trees during the dry season, when light availability is higher but water availability lower, may be explained by a deeper root system and a lower degree of deciduousness (Schnitzer 2005; but see Avalos and Mulkey 1999). Therefore, lianas may have the ability to 
remain photosynthetically active during periods of mild water stress (Cai et al. 2009), when many trees do not. Liana saplings tended to have higher maximum potential hydraulic conductivity than tree saplings, but did not differ in gas exchange rates, suggesting that liana saplings are hydraulically overbuilt during the (relatively wet) dry season. This suggests a fourth alternative explanation: although adult lianas may gain their competitive advantage during the dry season (Schnitzer 2005), liana saplings, that have smaller roots than adult lianas, may obtain their main growth advantage over trees during wet periods, when soil moisture conditions are high and they can achieve their full hydraulic conductivity at a lower risk of cavitation.

\section{Concluding remarks}

We evaluated how tree and liana saplings differ in physiological drought tolerance (i.e., $P_{50}$ ) and related traits that may explain their relatively high abundance in seasonal tropical forests. We found that lianas were less physiologically drought-tolerant than trees (i.e., they had a lower $P_{50}$ ) and tended to have higher $K_{\mathrm{h}}$, but, in contrast to other studies, we did not find any differences in any of the other measured traits. Possibly, lianas and trees are functionally very similar at the sapling stage, and the occurrences of lianas and trees in such seasonal tropical forests may only be explained by functional differences in later ontogenetic stages. Additionally, liana saplings may have a deep root system, which would allow them to remain active during the dry season. This suggests that lianas are drought-avoiding rather than physiologically drought-tolerant, in line with the dryseason growth advantage hypothesis (Schnitzer 2005). However, liana and tree saplings had similar $A$ area, possibly because the full potential hydraulic conductivity of lianas could not be realized in this dry season. A last explanation may therefore be that liana saplings obtain their growth advantage mainly during the wet season, when high hydraulic conductivity can be realized and cavitation risk is low. Future studies should show how hydraulic architecture and the relative performance of lianas and trees change during ontogenetic development and along gradients in water and light availability.

\section{Notes}

\section{Acknowledgments}

This research was financially supported by a Rubicon grant by the Netherlands Organisation for Scientific Research (NWO) to L.M., and by US National Science Foundation grants (NSF DEB-0613666, NSF DEB-0845071, NSF DEB-1019436) to S.A.S. M.v.d.S. was supported by a travel grant by Stichting Fonds Dr. Christine Buisman. We thank the Smitsonian Tropical Research Institute for the use of facilities, David Brassfield and Oldemar Valdez for field assistance and initial species identification, and two anonymous reviewers for valuable comments on an earlier manuscript.

\section{References}

Andrade JL, Meinzer FC, Goldstein G, Schnitzer SA (2005) Water uptake and transport in lianas and co-occurring trees of a seasonally dry tropical forest. Trees 19:282-289

Asner GP, Martin RE (2010) Canopy phylogenetic, chemical and spectral assembly in a lowland Amazonian forest. New Phytol 189:999-1012

Avalos G, Mulkey SS (1999) Photosynthetic acclimation of the liana Stigmaphyllon lindenianum to light changes in a tropical dry forest canopy. Oecologia 120:475-484

Avalos G, Mulkey SS, Kitajima K, Wright SJ (2007) Colonization strategies of two liana species in a tropical dry forest canopy. Biotropica 39:393-399 
Cai Z-Q, Poorter L, Cao K-F, Bongers F (2007) Seedling growth strategies in bauhinia species: comparing lianas and trees. Ann Bot 100:831-838

Cai Z-Q, Schnitzer SA, Bongers F (2009) Seasonal differences in leaf-level physiology give lianas a competitive advantage over trees in a tropical seasonal forest. Oecologia 161:25-33

DeWalt SJ, Schnitzer SA, Chave J, Bongers F, Burnham RJ, Clark DB, Ewango CEN, Gerwing JJ, Gortaire E, Hart T, Ibarra-Manrıquez G, Ickes K, Kenfack D, Macia MJ, Makana J-R, Martınez-Ramos M, Mascaro J, Moses S, Muller-Landau HC, Parren MPE, Parthasarathy N, Perez-Salicrup DR, Putz FE, Romero-Saltos H, Thomas D (2010) Annual rainfall and seasonality predict pan-tropical patterns of liana density and basal area. Biotropica 42:309-317

Engelbrecht BMJ, Comita LS, Condit R, Kursar TA, Tyree MT, Turner BL, Hubbell SP (2007) Drought sensitivity shapes species distribution patterns in tropical forests. Nature 447:80-82

Ennajeh ME, Nouiri M, Khemira H, Cochard H (2011) Improvement to the air-injection technique to estimate xylem vulnerability to cavitation. Trees 25:705-771

Ewers FW, Fisher JB (1991) Why vines have narrow stems: histological trends in Bauhinia (Fabaceae). Oecologia 88:233-237

Ewers FW, Fisher JB, Chiu S (1990) A survey of vessel dimensions in stems of tropical lianas and other growth forms. Oecologia 84:544-552

Ewers FW, Cochard H, Tyree MT (1997) A survey of root pressures in vines of a tropical lowland forest. Oecologia 110:191-196

Fisher JB, Guillermo AA, Ewers FW, Lopez-Portillo, J (1997) Survey of root pressure in tropical vines and woody species. Int J Plant Sci 158:44-50

Gilbert B, Wright J, Muller-Landau H (2006) Life history trade-offs in tropical trees and lianas. Ecology 87:12811288

Greenidge KNH (1952) An approach to the study of vessel length in hardwood species. Am J Bot 39:570-574

Gutiérrez M, Miguel-Chávez RS, Terrazas T (2009) Xylem conductivity and anatomical traits in diverse lianas and small tree species from a tropical forest of Southwest Mexico. Int J Bot 5:279-286

Hacke UG, Sperry JS (2001) Functional and ecological xylem autonomy. Perspect Plant Ecol Evol Syst 4:97-115

Hacke UG, Sperry JS, Wheeler JK, Castro L (2006) Scaling of angiosperm xylem structure with safety and efficiency. Tree Physiol 26:689-701

IPCC (2007) Climate Change 2007: The Physical Science Basis Working Group I Contribution to the IPCC Fourth Assessment Report. IPCC, Geneva

Jacobsen AL, Ewers FW, Pratt RB, Paddock WA, Davis SD (2005) Do xylem fibers affect vessel cavitation resistance? Plant Physiol 139:546-556

Maherali H, Pockman WT, Jackson RB (2004) Adaptive variation in the vulnerability of woody plants to xylem cavitation. Ecology 85:2184-2199

Maherali H, Moura CF, Caldeira MC, Willson CJ, Jackson RB (2006) Functional coordination between leaf gas exchange and vulnerability to xylem cavitation in temperate forest trees. Plant Cell Environ 29:571-583

Markesteijn L, Poorter L (2009) Seedling root morphology and biomass allocation of 62 tropical tree species in relation to drought- and shade-tolerance. J Ecol 97:311-325

Markesteijn L, Poorter L, Paz H, Sack L, Bongers F (2011a) Ecological differentiation in xylem cavitation resistance is associated with stem and leaf structural traits. Plant Cell Environ 34:137-148

Nardini A, Salleo S (2000) Limitation of stomatal conductance by hydraulic traits: sensing or preventing xylem cavitation? Trees Struct Funct 15:14-24 
Pammenter NW, Willigen CV (1998) A mathematical and statistical analysis of the curves illustrating vulnerability of xylem to cavitation. Tree Physiol 18:589-593

Poorter L, McDonald I, Alarcón A, Fichtler E, Licona J, Peña-Claros M, Sterck F, Villegas Z, Sass-Klaassen U (2010) The importance of wood traits and hydraulic conductance for the performance and life history strategies of 42 rainforest tree species. New Phytol 185:481-492

Putz FE (1983) Liana biomass and leaf area of a "tierra firme" forest in the Rio Negro basin, Venezuela. Biotropica 15:185-189

Restom TG, Nepstad DC (2004) Seedling growth dynamics of a deeply rooting liana in a secondary forest in eastern Amazonia. For Ecol Manag 190:109-118

Sakai S, Wright SJ (2008) Reproductive ecology of 21 coexisting Psychotria species (Rubiaceae): when is heterostyly lost? Biol J Linn Soc 93:125-134

Sanchez-Azofeifa GA, Castro-Esau KL, Kurz WA, Joyce A (2009) Monitoring carbon stocks in the tropics and the remote sensing operational limitations: from local to regional projects. Ecol Appl 19:480-494

Santiago LS, Wright SJ (2007) Leaf functional traits of tropical forest plants in relation to growth form. Funct Ecol 21:19-27

Santiago LS, Goldstein G, Meinzer FC, Fisher JB, Machado K, Woodruff D, Jones T (2004) Leaf photosynthetic traits scale with hydraulic conductivity and wood density in Panamanian forest canopy trees. Oecologia 140:543-550

Schnitzer SA (2005) A mechanistic explanation for global patterns of liana abundance and distribution. Am Nat 166:262-276

Schnitzer SA, Bongers F (2002) The ecology of lianas and their role in forests. Trends Ecol Evol 17:223-230

Schnitzer SA, Bongers F (2011) Increasing liana abundance and biomass in tropical forests: emerging patterns and putative mechanisms. Ecol Lett 14:397-406

Schnitzer SA, Parren MPE, Bongers F (2004) Recruitment of lianas into logging gaps and the effects of preharvest climber cutting in a lowland forest in Cameroon. For Ecol Manag 190:87-98

Schnitzer SA, Kuzee ME, Bongers F (2005) Disentangling above- and below-ground competition between lianas and trees in a tropical forest. J Ecol 93:1115-1125

Sperry JS, Donnely JR, Tyree MT (1988) A method for measuring hydraulic conductivity and embolism in xylem. Plant Cell Environ 11:35-40

Sterck F, Markesteijn L, Schieving F, Poorter L (2011) Functional traits determine trade-offs and niches in a tropical forest community. Proc Natl Acad Sci USA 108:20627-20632

Toledo M, Poorter L, Peña-Claros M, Alarcón A, Balcázar J, Leaño C, Licona JC, Llanque O, Vroomans V, Zuidema $P$, Bongers $F(2011)$ Climate is a stronger driver of tree and forest growth rates than soil and disturbance. J Ecol 99:254-264

Tyree MT, Ewers FW (1991) The hydraulic architecture of trees and other woody plants. New Phytol 119:345360

Tyree MT, Sperry JS (1989) Vulnerability of xylem to cavitation and embolism. Annu Rev Plant Physiol Plant Mol Biol 40:19-38

Van der Heijden GMF, Phillips OL (2008) What controls liana success in Neotropical forests? Glob Ecol Biogeogr 17:372-383

Welden CW, Hewett SW, Hubbell SP, Foster RB (1991) Sapling survival, growth, and recruitment: relationship to canopy height in a neotropical forest. Ecology 72:35-50

Westoby M, Falster DS, Moles AT, Vesk PA, Wright IJ (2002) Plant ecological strategies: some leading dimensions of variation between species. Annu Rev Ecol Syst 33:125-159 
Zhu S-D, Cao K-F (2009) Hydraulic properties and photosynthetic rates in co-occurring lianas and trees in a seasonal tropical rainforest in Southwestern China. Plant Ecol 204:295-304

Zhu S-D, Cao K-F (2010) Contrasting cost-benefit strategy between lianas and trees in a tropical seasonal rain forest in southwestern China. Oecologia 163:591-599 